\title{
Individual contributions to pooled-milt fertilizations of silver catfish Rhamdia quelen
}

\author{
Josiane Ribolli and Evoy Zaniboni-Filho
}

Supplementary stocking of fish in natural environments is a way to mitigate or compensate for the changes imposed on wild populations by river damming. Since little is known about the genetic composition of the supplementary stocks obtained by pooled-milt fertilization, the aim of this study was to determine the individual contributions of male jundiá Rhamdia quelen to offspring. Sperm from four males were mixed using equal volume of sperm from each of the males to fertilize eggs from only one female, kept in three blend with six males and three females. The proportions of larvae sired by the different males were quantified using five polymorphic DNA microsatellite loci. Analysis of these loci allowed paternal determination of $84 \%$ of the progeny, at a 0.972 combined exclusion probability. Broodstock milt had good fertilizing capacity when used alone, but when pooled the fertilizing capacities, its fertilizing possibility varied from 4 to $65 \%$. Results show that milt pools favor gametes of some males over others, thus reducing the progeny's genetic variability.

A estocagem de suplementação de peixes em ambientes naturais é uma das maneiras de mitigar ou compensar as alterações impostas pelo represamento dos rios às populações selvagens. Pouco se conhece sobre a composição genética dos estoques repovoadores obtidos através do manejo reprodutivo com fertilizações com o uso de pool de sêmen, de maneira que este trabalho teve como objetivo verificar a contribuição individual de machos de jundiá (Rhamdia quelen) na progênie. O mesmo volume de sêmen de quatro machos foi misturado para fertilizar os ovócitos de uma única fêmea, sendo mantidos em três combinações com seis machos e três fêmeas. A proporção de larvas geradas de diferentes machos foi quantificada através de cinco marcadores microssatélites. A análise dos cinco locus permitiu a determinação da paternidade de 84\% da progênie, com 0,972 de probabilidade de exclusão combinada. O sêmen dos reprodutores apresentou boa capacidade de fertilização quando utilizados separadamente, porém, quando utilizados em pool apresentaram capacidade de fertilização entre 4 a $65 \%$. Os resultados revelam que o pool de sêmen favorece alguns machos sobre outros, reduzindo a variabilidade genética da progênie.

Key words: Jundiá, Milt pool, Paternity, Genetic diversity.

\section{Introduction}

Environmental changes and overfishing have been broadly responsible for the reduction of genetic diversity in fish populations, which eventually leads to population decline and species extinction. These environmental changes are mainly caused by river pollution, eutrophication, construction of dams, fishing, and introduction of species (Agostinho et al., 2005).

Another important factor is the inadequate reproduction management techniques that may reduce the genetic variability of the hatchery stock and directly induce deleterious genetic effects on the wild fish populations (Allendorf \& Ryman, 1987; Hindar et al., 1991). Effects of fish stocking for supplementation or restoration of native populations has been discussed by several authors (Incerpi, 1996; Grimes, 1998; Waples, 1999). Miller \& Kapuscinski (2003) established the genetic guidelines for hatchery supplementation programs to reduce the impact of these managements, suggesting pool of milt from overlapping pairs of males when it is suspected that many males are infertile. Pooled milt is frequently used in hatcheries to reduce the impact of males with low sperm quality on the overall fertilization rate; it not only increases the probability of fertilization but also can improve genetic variability (Gharrett \& Shirley, 1985; Kaspar et al., 2008).

However, due to the lack of information, limited space in hatcheries and difficulty in using wild broodstock fish, a small number of males are repeatedly used to fertilize the oocytes of a large number of females; i.e., the semen of multiple males is added in sequence or as a pool just before water is added

Laboratório de Biologia e Cultivo de Peixes de Água Doce, Departamento de Aquicultura, Universidade Federal de Santa Catarina - UFSC. Rodovia SC 406, 3532, 88.066-000 Florianópolis, SC, Brazil. evoy@lapad.ufsc.br 
(Witlher, 1988). Additionally, optimized methods of artificial fertilization with knowledge about optimal sperm/egg ratio for fertilization are used. Paternal effects on early life history are often obscured and unexplained when sperm from multiple males are mixed during fertilization (Rideout et al., 2004). Previous research has demonstrated that spermatozoa competition in pooled-milt results in different paternity contributions from potential male parents, which reduces the effective size of the broodstock (Campton \& Utter, 1985; Allendorf \& Ryman, 1987). Reported variations in the fertilizing capacity of pooled-milt were confirmed by the verification of family relationships for Chinook salmon Oncorhynchus tshawytscha (Walbaum) (Gharret \& Shirley, 1985; Withler, 1988; Withler \& Beacham, 1994), rainbow trout Oncorhynchus mykiss (Walbaum) (Gile \& Ferguson, 1995; Herbinger, 1995), Atlantic halibut Hippoglossus hippoglossus (L.) (Ottesen et al., 2009) and common carp Cyprinus carpio (L.) (Kaspar et al., 2008).

Microsatellite markers are habitually used with success in paternity and identification tests because of the high frequency of polymorphisms and their wide distribution in the genomes of many eukaryotes (Tautz, 1989). Many authors have demonstrated the capacity of such markers to determine family relationships in cultured and wild fish populations (Herbinger et al., 1995; Fessehaye et al., 2006; Ottesen et al., 2009).

The present study investigated the fertilization and survival rates of $R$. quelen in different artificial crossings and also determined the individual paternal contributions in fertilization with pool semen from overlapping males using microsatellite markers.

\section{Material and Methods}

The study was conducted in the Laboratory of Freshwater Fish Biology and Fish Culture (LAPAD) and in the Laboratory of Plant Genetics and Developmental Physiology (LFDGV), at the Universidade Federal de Santa Catarina (UFSC). Rhamdia quelen (Quoy \& Gaimard) broodstock were caught from wild populations in the upper Uruguay River, in January of 2006. The individuals were subsequently brought to LAPAD where hormonal induction and extrusion were performed according to Woynarovich \& Horváth (1980). Gametes were collected from six males (M1, M2, M3, M4, M5 and M6) and three females (FA, FB and FC), in separate containers to quantify milt volume and number of oocytes.

To activate spermatozoa and stimulate fertilization, $100 \mathrm{ml}$ of water was added to the mixture of gametes. The eggs were then washed, hydrated and transferred to individual incubators for each treatment. The milt from each male was evaluated separately. To estimate the sperm concentration, $10 \mu \mathrm{l}$ of milt was diluted in $2 \mathrm{ml}$ of $5 \%$ formalin (in buffered saline), and the number of spermatozoa was counted in a Neubauer chamber under a microscope (400x), according to Mylonas et al. (1997). Spermatocrit values were determined for sperm collected in capillary tubes and centrifuged at $3000 \mathrm{rpm}$ during $5 \mathrm{~min}$. The result was expressed as the percentage of packed cell volume in relation to the total volume (Ciereszko \&
Dabrowski, 1993). The duration of sperm motility after activation with distilled water was measured considering the time of cessation of $80 \%$ of active movement (Carolsfeld et al., 2003).

One gram of oocytes from each female was fertilized with $40 \mu \mathrm{L}$ of a pool of semen (equal volume of semen from each of the four males) to determine the individual contribution of the males. Oocytes from female FA were fertilized with a pool of semen from males M1, M2, M3 and M4 (pool A); oocytes from female FB with a pool of semen M1, M2, M5 and M6 (pool B); and the oocytes from female FC with a pool from M3, M4, M5 and M6 (pool C), as shown in Table 1.

Table 1. Directed crossings of female (F) Rhamdia quelen oocytes with semen of a single male (M) (control) and with pooled semen from four males (treatment). ${ }^{1}$ pool A (M1+M2+M3+M4), ${ }^{2}$ pool B (M1+M2+M5+M6) and ${ }^{3}$ pool C (M3+M4+M5+M6).

\begin{tabular}{|c|c|c|c|c|c|c|c|c|c|}
\hline & \multicolumn{6}{|c|}{ Control } & \multicolumn{3}{|c|}{ Treatment } \\
\hline & M1 & M2 & M3 & M4 & M5 & M6 & pool $A^{1}$ & pool B ${ }^{2}$ & pool C 3 \\
\hline FA & $\mathrm{X}$ & $\mathrm{X}$ & $\mathrm{X}$ & $\mathrm{X}$ & & & $\mathrm{X}$ & & \\
\hline $\mathrm{FB}$ & $\mathrm{X}$ & $\mathrm{X}$ & & & $\mathrm{X}$ & $\mathrm{X}$ & & $\mathrm{X}$ & \\
\hline $\mathrm{FC}$ & & & $\mathrm{X}$ & $\mathrm{X}$ & $\mathrm{X}$ & $\mathrm{X}$ & & & $\mathrm{X}$ \\
\hline
\end{tabular}

A control group in which $1 \mathrm{~g}$ of oocytes from one female was fertilized with $40 \mu \mathrm{l}$ of sperm from one male was set to check egg quality, capacity of fertilization of each male and larval survival. For each crossing, sperm was mistured to oocytes in a beaker and $100 \mathrm{ml}$ of freshwater was added, then the mixture was moisturized, washed, and transferred to individual incubators. Fertilization success (number of eggs in blastopore closure stage x 100 x number of eggs observed ${ }^{-1}$ ) was determined the next day (approximately $15 \mathrm{~h}$ after fertilization) and total larval survival was determined $72 \mathrm{~h}$ post hatching. All evaluations were done in triplicate, and results were submitted to analysis of variance. When significant differences were detected between treatments, means were compared with Tukey's test at the 5\% significance level.

Samples of caudal fins of broodstock and eighty live larvae of each pool (sacrificed using overdose of eugenol) were fixed in $90 \%$ ethanol and stored in a freezer at $-20^{\circ} \mathrm{C}$. DNA was extracted following phenol/chloroform methodology (Monesi et al., 1998) and quantified on $0.8 \%$ agarose gels. For all samples, DNA concentration was diluted to $10 \mathrm{ng} / \mu \mathrm{l}$ for further analysis. The following five microsatellite markers were used for DNA analysis: Pcor1 and Pcor2 (Revaldaves et al., 2005), Pc17 and Pc97 (Moeser \& Bermingham, 2005), and Rh1 (F: 5'-TTACTCGGGATACGATGC-3' and R: 5'TTGTCAGAGTGCCAAAGG-3'). PCR amplifications involved 3 min of denaturation at $95^{\circ} \mathrm{C}$, followed by 30 cycles of consecutively $1 \mathrm{~min}$ denaturation at $95^{\circ} \mathrm{C}, 1 \mathrm{~min}$ annealing at specific temperatures (Pcor1, $50^{\circ} \mathrm{C}$; Pcor2, $51^{\circ} \mathrm{C}$; Rh1, 56 ${ }^{\circ} \mathrm{C}$; Pc17, 53 ${ }^{\circ} \mathrm{C}$; Pc97, $\left.54^{\circ} \mathrm{C}\right), 1$ min elongation at $72^{\circ} \mathrm{C}$ and a final extension for $10 \mathrm{~min}$ at $72^{\circ} \mathrm{C}$. Amplification products ran on $4 \%$ polyacrylamide denaturing gels and stained as described 
by Creste et al. (2001).

Paternity inference was initially performed using an exclusion-based approach starting from the genotypes at five loci. We look for mismatches between parents and offspring using the matrix outputs from the software Cervus version 3.0 (Marshall et al., 1998). The likelihood-based method implemented in the same program was applied to obtain the probabilities of the most likely parents or couples for comparison with the exclusion approach. Simulation parameters involved 10,000 bootstrap cycles from broodstock allele frequencies. A default genotyping error rate of $1 \%$ was used and it assumed that all parents were sampled. The analysis multilocus genotypes within family groups, diversity estimators (allele number, heterozygosity, polymorphic information content) and the two exclusion probabilities (Excl1, Excl2) for each locus and for all loci, were calculated using the allele frequency option of Cervus.

\section{Results}

Spermatocrit values were not good indicators of fertilization capacity in the control crossings, as a positive correlation was found only in pool C $(r=0.44)$ and not in any other treatment. M1 presented both a low spermatocrit value (7.5\%) and a high fertilization rate in the crossing between female A and male 1 (FAM1) (93.4\%) (p < 0.05). In contrast, M6 presented a high spermatocrit value (23.9\%) but produced the lowest fertilization rate in the FBM6 crossing (77.1\%) (p < 0.05 ) (Table 2). Sperm concentrations ranged from 1.72 to 4.76 $\mathrm{x} 10^{10}$ spermatozoa $\mathrm{ml}^{-1}$, with higher concentrations for male M3 than M1, M4, M5 or M6 (p < 0.05). Spermatocrit values ranged from 4.4 to $24.6 \%$, with the highest values observed for males M3, M4 and M6 (24.6, 23.5, and 23.9\%, respectively).

Sperm motility durations (20\% of active sperm) ranged from 38.5 to 97.8 seconds (M1 and M5). The fertilization rate was above $77 \%$ in control and $83 \%$ in the pooled-milt crosses. There were no significant differences in the rates at which the sperm of different males fertilized the oocytes of female
FA ( $p>0.05$ ), whereas the fertilization rates of crossings FBM1 and FBM5 (95.4 and 98.5\%, respectively) were higher than that of crossing FBM6 (77.1\%). Crossings with female FC presented a significant difference only between the fertilization rates with M4 and M6 (Table 2).

Larval survival 20 days post-hatching varied between 22 and $99 \%$. The survival rate in pool B was higher than in pool $A(p<0.05)$. No significant difference in survival was observed when the oocytes of a given female were fertilized by the milt of different males; however, in crossings FAM1, FAM3 and FAM4, survival was significantly lower than in FBM5, FBM6, FCM3, FCM4 and FCM5 ( $<$ 0.05) (Fig. 1).

Some males usually present higher fertilization capacity than others, but this ability can change when crossed with different females or the semen is pooled with distinct males. In pool A, male M4 had higher fertilizing capacity than the others, fathering $63 \%$ of the progeny $(\mathrm{p}<0.05)$. Males $\mathrm{M} 1$, M2, M3 contributed 20.4, 12.5 and $10.2 \%$, respectively, but the control crosses did not show significant differences in the fertilization rates or larval survival among the male fish that fertilized oocytes from female FA. In pool B, male M2 had higher fertilizing capacity (41.7\%) than males M1 and M5 (16.6 and $10.3 \%$, respectively), but the fertilization rates in crosses FBM1 and FBM5 were higher than in cross FBM2 ( $<0.05)$. The number of M6 descendants (36.7\%) in pool $\mathrm{C}$ was higher than that of M3 (17.8\%) or M5 (13.5\%). In summary, males M4 and M6 contributed more in the pooled-milt fertilizations, male M2 had higher fertilizing capacity only in pool B, and M1, M3 and M5 behaved similarly in the two pooled crosses with consistently low contributions to the progeny (Fig. 1).

The total number of alleles per locus observed ranged from five (Pc17) to eight (Pcor2 and Rh1). Probabilities of exclusion per locus ranged from 0.129 to 0.474 , when the information for the female parent was known (Excl). The mean heterozygosity was 0.770 and the mean polymorphic information content was 0.706 . Combined exclusion probability was 0.972 when the genotype of the other parent was known (Table 3), determined 201 offspring (84\%) from a

Table 2. Mean values and standard deviation of sperm concentration, spermatocrit, sperm motility duration, fertilization rate,

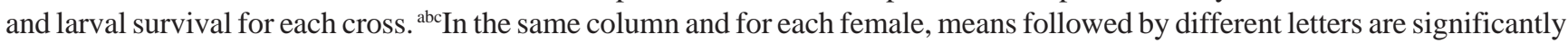
different $(\mathrm{p}<0.05)$.

\begin{tabular}{ccccccc}
\hline Female & Male & Concentration (cells/ml) & Spermatocrit (\%) & Motility (S) & Fertilization (\%) & Survival (\%) \\
\hline A & 1 & $1.89 \pm 0.31 \times 10^{10 \mathrm{~b}}$ & $7.5 \pm 0.57^{\mathrm{c}}$ & $38.5 \pm 8.3^{\mathrm{bc}}$ & $93.4 \pm 4.8^{\mathrm{a}}$ & $22.4 \pm 13.1^{\mathrm{b}}$ \\
& 2 & $3.10 \pm 0.89 \times 10^{10 \mathrm{ab}}$ & $7.0 \pm 0.01^{\mathrm{c}}$ & $40.3 \pm 2.1^{\mathrm{c}}$ & $89.8 \pm 4.2^{\mathrm{abc}}$ & $62.5 \pm 20.6^{\mathrm{ab}}$ \\
& 3 & $4.80 \pm 0.85 \times 10^{10 \mathrm{a}}$ & $24.6 \pm 0.48^{\mathrm{a}}$ & $62.8 \pm 8.8^{\mathrm{ab}}$ & $89.9 \pm 6.6^{\mathrm{abc}}$ & $26.1 \pm 11.3^{\mathrm{b}}$ \\
& 4 & $2.53 \pm 0.71 \times 10^{10 \mathrm{~b}}$ & $23.5 \pm 0.58^{\mathrm{b}}$ & $63.5 \pm 7.3^{\mathrm{ab}}$ & $86.1 \pm 7.3^{\mathrm{abc}}$ & $22.9 \pm 3.9^{\mathrm{b}}$ \\
& pool A & - & - & - & $83.4 \pm 8.5^{\mathrm{abc}}$ & $38.1 \pm 19.1^{\mathrm{b}}$ \\
\hline B & 1 & $1.89 \pm 0.31 \times 10^{10 \mathrm{~b}}$ & $7.5 \pm 0.57^{\mathrm{c}}$ & $38.5 \pm 8.3^{\mathrm{bc}}$ & $95.4 \pm 1.7^{\mathrm{ab}}$ & $54.7 \pm 34.7^{\mathrm{ab}}$ \\
& 2 & $3.10 \pm 0.89 \times 10^{10 \mathrm{ab}}$ & $7.0 \pm 0.01^{\mathrm{c}}$ & $40.3 \pm 2.1^{\mathrm{c}}$ & $91.7 \pm 2.5^{\mathrm{abc}}$ & $68.4 \pm 4.8^{\mathrm{ab}}$ \\
& 5 & $2.78 \pm 0.36 \times 10^{10 \mathrm{~b}}$ & $4.4 \pm 0.48^{\mathrm{d}}$ & $97.8 \pm 8.1^{\mathrm{a}}$ & $98.5 \pm 1.0^{\mathrm{a}}$ & $89.8 \pm 10.8^{\mathrm{a}}$ \\
& 6 & $1.72 \pm 0.06 \times 10^{10 \mathrm{~b}}$ & $23.9 \pm 0.48^{\mathrm{ab}}$ & $74.5 \pm 5.2^{\mathrm{bc}}$ & $77.1 \pm 2.7^{\mathrm{c}}$ & $81.5 \pm 25.0^{\mathrm{a}}$ \\
& pool B & - & - & - & $98.0 \pm 0.4^{\mathrm{a}}$ & $99.5 \pm 0.2^{\mathrm{a}}$ \\
\hline C & 3 & $4.80 \pm 0.85 \times 10^{10 \mathrm{a}}$ & $24.6 \pm 0.48^{\mathrm{a}}$ & $62.8 \pm 8.8^{\mathrm{ab}}$ & $93.6 \pm 2.3^{\mathrm{ab}}$ & $98.0 \pm 0.6^{\mathrm{a}}$ \\
& 4 & $2.53 \pm 0.71 \times 10^{10 \mathrm{~b}}$ & $23.5 \pm 0.58^{\mathrm{b}}$ & $63.5 \pm 7.3^{\mathrm{ab}}$ & $98.2 \pm 1.0^{\mathrm{a}}$ & $86.7 \pm 21.7^{\mathrm{a}}$ \\
& 5 & $2.78 \pm 0.36 \times 10^{10 \mathrm{~b}}$ & $4.4 \pm 0.48^{\mathrm{d}}$ & $97.8 \pm 8.1^{\mathrm{a}}$ & $91.7 \pm 1.7^{\mathrm{abc}}$ & $76.2 \pm 5.8^{\mathrm{a}}$ \\
& 6 & $1.70 \pm 0.06 \times 10^{10 \mathrm{~b}}$ & $23.9 \pm 0.48^{\mathrm{ab}}$ & $74.5 \pm 5.2^{\mathrm{bc}}$ & $81.2 \pm 6.4^{\mathrm{bc}}$ & $66.2 \pm 12.3^{\mathrm{ab}}$ \\
& pool C & - & - & - & $91.7 \pm 1.8^{\mathrm{abc}}$ & $61.4 \pm 4.0^{\mathrm{ab}}$ \\
\hline
\end{tabular}



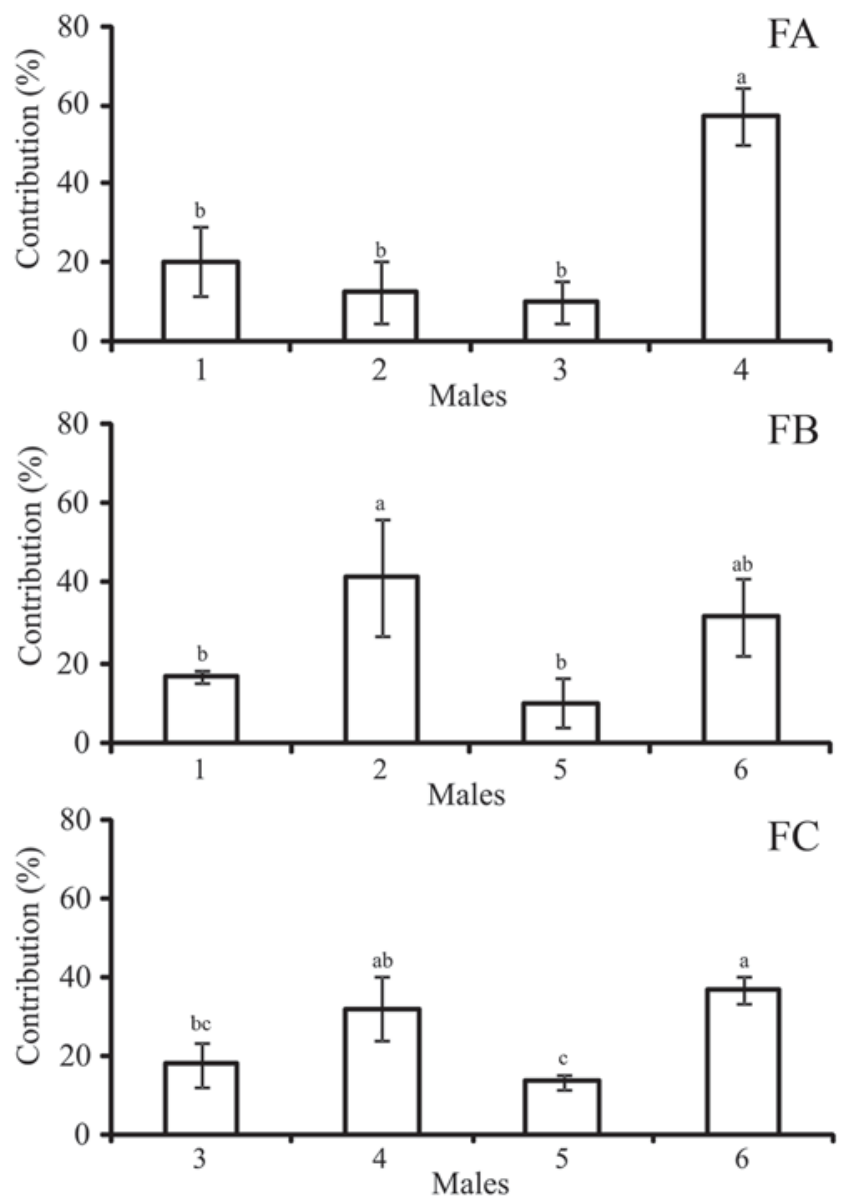

Fig. 1. Mean values and standard deviation of the relative contribution of each male to the progeny when the oocytes of each female (FA, FB, FC) were fertilized with pooled semen from four males (pool A: M1+M2+M3+M4; pool B: M1+M2+M5+M6; pool C: M3+M4+M5+M6).

total of 239 offspring analyzed. The remaining incompatibilities were considered as false exclusions due to null alleles and mutations, because all breeders had been genotyped and the number of incompatible loci.

Frequencies of null alleles in the broodstock as estimated by Cervus 3.0, ranged between 1 and $6 \%$ for all loci (Table 3).

Table 3. Locus SSR, number of alleles ( $k$ ), number of individuals successfully genotyped (n), range of observed alleles in pb (size), observed heterozygosity (Ho), expected heterozygosity (He), polymorphic information content (PIC), probabilities of exclusion (EP) and null alleles estimated by Cervus version 3.0 at a frequency $>0.05$.

\begin{tabular}{lcccccccc}
\hline Locus & $k$ & $\mathrm{n}$ & Size $(\mathrm{pb})$ & Ho & He & PIC & EP & Null alleles \\
\hline Pcor1 & 6 & 229 & $82-102$ & 0.878 & 0.823 & 0.797 & 0.466 & -0.0359 \\
Pcor2 & 8 & 219 & $180-280$ & 0.941 & 0.826 & 0.800 & 0.474 & -0.0672 \\
Rh1 & 8 & 219 & $220-290$ & 0.872 & 0.816 & 0.791 & 0.464 & -0.0396 \\
Pc17 & 5 & 227 & $240-262$ & 0.714 & 0.734 & 0.686 & 0.300 & +0.0164 \\
P97 & 6 & 216 & $250-290$ & 0.449 & 0.475 & 0.457 & 0.129 & +0.0635 \\
\hline
\end{tabular}

\section{Discussion}

In crosses with pooled-milt, differential contributions from each male result in a reduction of the effective size of the founding stock. According to Falconer \& Mackay (1996), this reduction depends on the total number of individuals that contribute with genes to the next generation. One of the main practical problems caused by pooled sperm is unequal representation of males used for fertilization, causing reduction of the effective size of the population (Kaspar et al., 2008). In this study, we verified that pooling milt before insemination of oocytes does not confirm that the number of descendants of each male parent will be proportional to the volume of donated milt. All male parental fish demonstrated fertilization capacity in individual crosses, however, when pooled, this rate varied between 4 and $65 \%$. Considering that all tested males exhibited high fertilization rates in the control crosses, the obtained results suggest the dominance of some males over others during the pooled-milt fertilization. Spermatozoa competition in the fertilization of an egg pool with pooled milt of Atlantic salmon was observed by Campton \& Utter (1985). Witlher (1988) found dominance of some males of Oncorhynchus tshawytscha in crosses with pooled milt, with variations of 1.4 to $75.6 \%$. According to this author, variability among males is not simply the result of individual differences, but also of individual variation throughout the reproductive season, so that some males can fertilize the oocytes individually but cannot make a significant contribution when applied in a pool. Some studies have been presenting differences in the success of fertilizations with a pool of semen (Rideout et al., 2004; Ottesen et al., 2009).

Hormonal induction of the silvercatfish broodstock resulted in high fertilization rates in the control crosses, but differences in fertilizing capacity of the same male were observed when milt was pooled with different males and used to fertilize eggs from distinct female (e.g. M2 contributed with $12.5 \%$ in pool A and $31.9 \%$ in pool B). This is consistent with results of Withler (1988) for O. tshawytscha, who related the variation in fertilizing capacity observed in some species to the possible interaction among male gametes or to the different females involved in the fertilization. In fertilizations of pooledmilt, if all males had the same reproductive success, any offspring has an equal chance to be originated from each of the males, following a Poisson distribution:

$$
N_{e m}=N_{m}-1 / K_{m}
$$

where $N_{e m}$ is the number effective of males, $N_{m}$ is the number of males used and $K_{m}$ is the mean number of progenies per male. The theoretical $N_{e m}$ in the absence of competition was 3.98 on average for all pooled-milt of jundiá. Kimura \& Crow (1963) exhibit a parameter that is modified by unequal paternal contributions and may be used to estimate the genetically effective size of a population created from progeny groups of pooled-milt fertilizations:

$$
N_{e m}=\left(N_{m} \cdot K_{m}-1\right) /\left(K_{m}-1+V_{m} / K_{m}\right)
$$

where $V_{m}$ is the variance of the number of progeny per male. The true $N_{e m}$ was 1.93 on average (0.85-3.66) in Pool A; 2.92 
(1.67-3.77) in Pool B and 3.40 (2.77-3.77) in Pool C. The fertilization procedure used in this research produced a mean reduction in the $N_{e m}$ of $30.91 \%$. This results show that using a mixture of sperm leads to an important reduction of the effective number of males. Similar results were found by Withler (1988) and Withler \& Beacham (1994) with average reduction in $N_{e m}$ as $31.4 \%$ for Chinook salmon and Kaspar et al. (2007) showing a mean reduction of $42.4 \%$ for common carp.

Among many factors that interfere in the success of fertilization, sperm motility is considered the main characteristic (Birkhead \& Møller, 1998; Rakitin, 1999). In Atlantic halibut, sperm velocity and the number of motile sperm are major components in the competition for fertilization (Ottssen et al., 2009), and in Atlantic salmon, sperm speed is considered the main factor determining the success in sperm competition (Gage et al., 2004). The duration of sperm motility of silver catfish was not correlated with the fertilization rate in these crosses. Male M1 showed the lowest sperm motility time but not the lower ability of fertilization; nevertheless, male M5 had the higher motility time and the lowest fertilization rate in both pooled-milt fertilizations that it was used. Some studies collaborate with our results (Rakitin, 1999; Casselman et al., 2006); however sperm motility is still considered the most important parameter for fertilization success in other fish species (Lahnsteiner et al., 1998; Rurangwa et al., 2001; Ottesen et al., 2009). Sperm concentration and spermatocrit value were also not correlated with the fertilization rate for silvercatfish. According to Gharrett \& Shirley (1985) and Withler (1988), the variations in male fertilization potential cannot be described by spermatocrit values and sperm cell size, which change between males.

The uneven participation of parental gametes cannot be attributed only to the quality of semen parameters, because it does not necessarily indicate the best one for competitiveness fertilizations in pooled-milt. The methodology used during fertilization can favor the gametes of a certain individual over others (Hill, 1979). The reproductive success of individual male of $R$. quelen in the pooled milt treatments was independent of the fertilized females and also the interactions with other silvercatfish male. These differences reflect the complexity of pooling sperm for fertilization. The maximum effective size of the foundation stock can be guaranteed by using controlled crosses with fertilizations in small individual recipient before being grouped into incubators. In this condition, all males have the same opportunity to leave their genetic information and, thus, this management can be recommended for maintain genetic diversity in the progeny.

\section{Acknowledgements}

We are grateful to Adriana Dantas, Maguida Fabiana Silva and Cláudio Rodrigues Melo for providing technical assistance in the genetic analyses, and to Marcos Weingartner for the collaboration in the reproduction and larval rearing. We also would like to thank Anderson Luis Alves and Cláudio Oliveira by providing the microsatellites sequences and Samara Hermes Silva for comments and suggestions on the manuscript.

\section{Literature Cited}

Agostinho, A. A., S. Thomaz \& L. C. Gomes. 2005. Conservation of the Biodiversity of Brazil's Inland Waters. Conservation Biology, 19(3): 646-652.

Allendorf, F. W. \& N. Ryman. 1987. Genetic management of hatchery stocks. Pp. 141-159. In: Ryman, N. \& F. Utter (Eds.). Population genetics and fishery management. Seattle, University of Washington Press, 420p.

Birkhead, T. R. \& A. P. Møller. 1998b. Sperm competition, sexual selection and different routes to fitness. Pp. 757-781. In: Birkhead, T. R. \& A. P. Møller (Eds.). Sperm competition and sexual selection. San Diego, Academic Press, 826p.

Campton, D. E. \& F. M. Utter. 1985. Natural hybridization between steelhead trout (Salmo gairdneri) and coastal cutthroat trout (Salmo clarki clarki) in two Puget Sound streams. Canadian Journal of Fisheries and Aquatic Science, 42(1): 110-119.

Carolsfeld, J., H. P. Godinho, E. Zaniboni Filho \& B. J. Harvey. 2003. Cryopreservation of sperm in Brazilian migratory fish conservation. Journal of Fish Biology, 63(2): 472-489.

Casselman, S. J., A. I. Schulte-Hostedde \& R. Montgomerie. 2006. Sperm quality influences male fertilization success in walleye (Sander vitreus). Canadian Journal of Fisheries and Aquatic Sciences, 63: 2119-2125.

Ciereszko, A. \& K. Dabrowski. 1993. Estimation of sperm concentration of rainbow trout, whitefish and yellow perch using a spectrophotometric technique. Aquaculture, 109: 367-373.

Creste, S., A. Tulmann Neto \& A. Figueira. 2001. Detection of single sequence repeat polymorphisms in denaturing polyacrilamide sequencing gels by silver staining. Plant Molecular Biology Reporter, 19(4): 299-306.

Falconer, D. S. \& T. F. C. Mackay. 1996. Introduction to quantitative genetic. London, Longman, 464p.

Fessehaye, Y., Z. El-Bialy, M. A. Rezk, R. Crooijmans, H. Bovenhuis \& H. Komen. 2006. Mating systems and male reproductive success in Nile tilapia (Oreochromis niloticus) in breeding hapas: a microsatellite analysis. Aquaculture, 256: 148-158.

Gage, M. J. G., C. P. Macfarlane \& S. Yeates. 2004. Spermatozoal traits and sperm competition in Atlantic salmon: relative sperm velocity is the primary determinant of fertilization success. Current biology, 14: 44-47.

Gharrett, A. J. \& S. M. Shirley. 1985. A genetic examination of spawning methodology in a salmon hatchery. Aquaculture, 47: 245-256.

Gile, S. \& M. M. Fergunson. 1995. Factors affecting male potency in pooled gamete crosses of rainbow trout, Oncorhynchus mykiss. Environmental Biology of Fishes, 42: 267-275.

Grimes, C. B. 1998. Marine stock enhancement: sound management or techno-arrogance? Fisheries, 23: 18-23.

Herbinger, C. M., R. W. Doyle, E. R. Pitman, D. Paquet, K. A. Mesa, D. B. Morris, J. M. Wright \& D. Cook. 1995. DNA fingerprint based analysis of paternal and maternal effects on offspring growth and survival in communally reared rainbow trout. Aquaculture, 137: 245-256.

Hill, W. G. 1979. A note on effective population size with overlapping generations. Genetics, 92: 317-322.

Hindar, K., N. Ryman \& F. Utter. 1991. Genetic effects of cultured fish on natural fish populations. Canadian Journal of Fisheries and Aquatic Sciences, 48: 945-957. 
Incerpi, A. 1996. Hatchery bashing: a useless pastime. Fisheries, 21(5): 28.

Kaspar, V., K. Kohlmann, M. Vandeputte, M. Rodina, D. Gela, M. Kocour, S. M. Hadi Alavi, M. Hulak \& O. Linhart. 2007. Equalization of sperm concentrations in a pool of sperm does not prevent large variance in males contribution in common carp progeny. Aquaculture, 272(1): 204-209.

Kaspar, V., M. Vandeputte, K. Kohlmann, M. Hulak, M. Rodina, D. Gela, M. Kocour \& O. Linhart. 2008. A proposal and case study towards a conceptual approach of validating sperm competition in common carp (Cyprinus carpio L.), with practical implications for hatchery procedures. Journal of Applied Ichthyology, 24: 406-409.

Kimura, M. \& J. F. Crow. 1963. The measurement of effective population numbers. Evolution, 17: 279-288.

Lahnsteiner, F., B. Berger, T. Weismanu \& R. A. Patzner. 1998. Evaluation of the semen quality of the rainbow trout, Oncorhynchus mykiss, by sperm motility, seminal plasma parameters, and spermatozoal metabolism. Aquaculture, 163: 163-181.

Marshall, T. C., J. Slate, L. E. B. Kruuk \& J. M. Pemberton. 1998. Statistical confidence for likelihood-based paternity inference in natural populations. Molecular Ecology, 7: 639-655.

Miller, L. M. \& A. R. Kapuscinski. 2003. Genetic guidelines for hatchery supplementation programs. Pp. 329-356. In: Hallerman, E. M. (Ed.). Population genetics: principles and applications for fisheries scientists. Bethesda, MD American Fisheries Society, 458p.

Moeser, A. A. \& E. Bermingham. 2005. Isolation and characterization of eight microsatellite loci for the Neotropical freshwater catfish Pimelodella chagresi (Teleostei: Pimelodidae). Molecular Ecology Notes, 5(2): 363-365.

Monesi, N., M. Jacobs-Lorena \& M. L. Pacó-Larson. 1998. The DNA puff gene BhC4-1 of Bradysia hygida is specifically transcribed in early prepupal salivary glands of Drosophila melanogaster. Chromosoma, 107(8): 559-569.

Mylonas, C. C., A. P. Scott, E. L. Vermeirssen \& Y. Zohar. 1997. Changes in plasma gonadotropin II and sex steroid hormones, and sperm production of striped bass after treatment with controlled-release gonadotropin-releasing hormone agonistdelivery systems. Biology of Reproduction, 57: 669-675.

Ottesen, O. H., I. Babiak \& G. Dahle. 2009. Sperm competition and fertilization success of Atlantic halibut (Hippoglossus hippoglossus L.). Aquaculture, 286(3-4): 240-245.

Rakitin, A. 1999. Body size and reproductive success in Atlantic cod, Gadus morhua L. Unpublished Ph.D. Thesis, Faculty of Graduate Studies of the University of Guelph, Guelph, 151p.

Revaldaves, E., L. H. G. Pereira, F. Foresti \& C. Oliveira. 2005. Isolation and characterization of microsatellite loci in Pseudoplatystoma corruscans (Siluriformes:Pimelodidae) and cross-species amplification. Molecular Ecology Notes, 5: 463465.

Rideout R. M., E. A. Trippel \& M. K. Litvak. 2004. Paternal effects on haddock, Melanogrammus aeglefinus L., early life history traits. Journal of Fish Biology, 64: 695-701

Rurangwa, E., F. A. M. Volckaert, G. Huyskens, D. E. Kime \& F. Ollevier. 2001. Quality control of refrigerated and cryopreserved semen using computer-assisted sperm analysis (CASA), viable staining and standardized fertilization in African catfish, Clarias gariepinus. Theriogenology, 55: 751-769.

Tautz, D. 1989. Hypervariability of simple sequences as a general source for polymorphic DNA markers. Nucleic Acids Research, 17: 6463-6471.
Waples, R. S. 1991. Genetic interactions between hatchery and wild salmonids: lessons from the Pacific Northwest. Canadian Journal of Fisheries and Aquatic Sciences, 48: 124-133.

Witlher, R. E. 1988. Genetic consequences of fertilizing Chinook Salmon (Oncorhynchus tshawytscha) eggs with pooled milt. Aquaculture, 68: 15-25.

Withler, R. E. \& T. D. Beacham. 1994. Genetic consequences of the simultaneous or sequential addition of semen from multiple males during hatchery spawning of chinook salmon (Oncorhynchus tshawytscha). Aquaculture, 126: 11-23.

Woynarovich, E. \& L. Horváth. 1980. The artificial propagation of warm-water finfishes - a manual for extension. Fisheries Technical Paper 201. Roma, FAO, 183p.

Accepted October 12, 2009

Published December 18, 2009 